\title{
MARINE POLLUTION DITINJAU DARI PERBANDINGAN PRAKTIK NEGARA TERHADAP INSTRUMEN HUKUM INTERNASIONAL
}

\author{
Neneng Yuni \\ Mahasiswa Fakultas Hukum, Universitas Padjadjaran, Jatinangor \\ Email Corresponding: nenengyuni18@gmail.com
}

Received: 29 Mei 2020

Accepted: 26 Agustus 2020

\begin{abstract}
Abstrak Penelitian ini bertujuan untuk mengurai strategi beberapa negara, serta menganalisis keberlakuan instrumen hukum internasional dalam menyikapi marine pollution. Penelitian ini menggunakan pendekatan perundang-undangan (statute approach) dan pendekatan konseptual (conceptual approach) dimana jenis dan sumber data yaitu terdiri dari bahan hukum primer dan sekunder. Selanjutnya, sumber data yang telah dikumpulkan akan diidentifikasi, klasifikasi dan sistematisasi sesuai permasalahan penelitian. Analisis data dalam penelitian ini dilakukan melalui cara menelaah sumber ataupun bahan hukum tertulis. Hasil telaah tersebut diinterpretasikan menggunakan metode interpretasi yang sistematis, gramatikal, dan, teleologis. Hasil penelitian menguraikan bahwa strategi dalam menyikapi marine pollution, terdiri dari empat negara, antara lain Australia memilih untuk meningkatkan pemahaman masyarakat terkait lingkungan di laut. Indonesia memilih untuk membuat payung hukum serta mendorong pemanfaatan sampah plastik sebagai campuran aspal. Amerika memilih untuk memprioritaskan peraturan perundang-undangan, antara lain Public Law Nomor 92-500 Tahun 1972 tentang Federal Water Pollution Control Act Amendments of 1972 dan Public Law Nomor 109-449 Tahun 2006 tentang Marine Debris Research, Prevention, and Reduction Act. Jepang melalui Kementerian Lingkungan Hidup memilih untuk melakukan pembersihan di lautan, serta memberlakukan kepada masyarakat terkait daur ulang sampah. Lebih lanjut, instrumen hukum internasional dalam menyikapi marine pollution, antara lain Protocol 1996 dan UNCLOS, serta Protocol MARPOL. Protocol 1996 dan UNCLOS saling berkaitan dan tidak bisa dipisahkan, namun sebagian belum meratifikasi Protocol MARPOL sebagai bagian dari pelaksana Protocol 1996. Adapun saran-saran dalam menyikapi marine pollution secara umum, antara lain pertama, memberikan edukasi kepada masyarakat internasional agar membentuk kepeduliannya terhadap lingkungan laut. Kedua, meratifikasi instrumen hukum internasional terkait marine pollution sehingga terjadi sinkronisasi dan harmonisasi hukum yang dapat dipertanggungjawabkan oleh seluruh masyarakat internasional. Dengan demikian, strategi mengatasi marine pollution dapat diatasi melalui keterhubungan antara perbandingan praktik negara dan instrumen hukum internasional.
\end{abstract}

Kata Kunci: Instrumen Hukum Internasional; Marine Pollution; Protocol 1996; Protocol MARPOL; UNCLOS. 


\section{PENDAHULUAN}

Pencemaran laut atau marine pollution menjadi salah satu isu global di berbagai negara. Khususnya, di Indonesia, Australia, Amerika dan jepang. Pada tahun 1967 terjadi marine pollution terbesar, ketika Kapal Tanker Torrey Canyon kandas di Pantai Selatan Inggris yang menumpahkan 35 Gallons crude oil. ${ }^{1}$ Kasus lainnya yaitu tumpahnya minyak oleh Kapal Showa Maru 1975 diperairan Selat Malaka serta tercemarnya air laut yang disebabkan oleh tumpahan minyak yang berasal dari pengeboran lepas pantai di laut Australia memberikan dampak kerusakan pada ekosistem dan ekologi laut hingga ke perairan Indonesia. ${ }^{2}$ Pada tahun ini kasus bocornya pertambangan lepas pantai di teluk Meksiko yang mengakibatkan luas pencemaran hingga perairan laut Amerika. ${ }^{3}$ Kasus selanjutnya pada tanggal 25 Mei 2010 dengan ditabraknya kapal Tangker MT. Bunga Kelana (berbendera Malaysia) oleh Kapal Cargo MV. Waily (berbendera St. Vincent \& Grenada), yang menumpahkan 2000 Ton minyak mentah (crude oil) di Selat Singapura. ${ }^{4}$

Dalam empat bulan pertama 2015, 15.000 wadah plastik telah tersapu di pantai Jepang dimana sebagian besar sampah berasal dari Korea Selatan dan Cina karena hampir semua yang jatuh di perairan lepas pantai selatan berakhir di pantai Jepang. ${ }^{5}$ Berbagai kasus yang sudah masuk ke International Court of Justice diantaranya, Pollution of the Muktuk Ocean through Ocean Fertilization, Construction of a Road in Costa Rica along the San Juan River, Pulp Mills on the River Uruguay, dan The Mox Plant Case menerangkan tentang marine pollution belum menjadi tanggung jawab secara internasional. Hal ini dibuktikan dengan pertama, Menurut Asosiasi Industri Aromatik Olefin dan Plastik Indonesia (INAPLAS), konsumsi plastik nasional masih didominasi bentuk kemasan (65\%). ${ }^{6}$ Selaras dengan data World Bank tahun 2017, komposisi sampah plastik yang ditemukan di laut Indonesia juga didominasi oleh kantung plastik sebanyak $52 \%$ dan plastik kemasan sebanyak $16 \% .^{7}$ Kedua, berdasarkan perkiraan World Economic Forum, pada tahun 2050 nanti akan banyak plastik di laut dibandingkan dengan ikan sesuai dengan data bank dunia menujukkan bahwa kota-kota di Indonesia menyumbang sekitar 3,22 juta ton sampah ke lautan termasuk sampah plastik. ${ }^{8}$ Ketiga, United Nations Convention on the Law of the Sea (selanjutnya disebut UNCLOS) yang masih bersifat general terhadap marine pollution, serta tidak adanya kehendak untuk meratifikasi

\footnotetext{
${ }^{1}$ Ahmad Sofyan. (2010). Tanggung Jawab dalam Pencemaran Laut yang Disebabkan oleh Minyak Menurut Hukum Internasional. Inspirasi, Universitas Tadulako, 10, hlm. 139.

${ }^{2}$ Ibid., hlm. 140.

${ }^{3}$ Ibid.

${ }^{4}$ Ibid.

${ }^{5}$ Editorial. (2015, 11 November). The Pollution Crisis in Sea of Japan. Dalam Renewable Energy World. Diakses pada tanggal 27 Mei 2020.

${ }^{6}$ Sherly Puspita. (2018, 19 Agustus). Indonesia Penyumbang Sampah Plastik Terbesar Kedua di Dunia. Dalam Megapolitan, Kompas.com. Diakses pada tanggal 27 Mei 2020.

${ }^{7}$ Safri Burhanuddin. $(2017,11$ September). Improving Solid Waste Management Capacity as a Tool for Combating Marine Plastic Debris Issue. Artikel dipresentasikan pada National Conference on Waste To Energy, Jakarta: Coordinating Ministry for Maritime Affairs Republic of Indonesia.

${ }^{8}$ Ahmad Surya Widyansyah. (2020, 4 Maret). Kurangi Sampah Plastik Lautan, Apa Strategi Indonesia? Dalam suara. com. Diakses pada tanggal 27 Mei 2020.
} 
International Maritime Organization Tahun 1973 tentang International Convention for the Prevention of Pollution from Ships dan dicabut dengan International Maritime Organization tentang Protocol of 1978 Relating to the International Convention for the Prevention of Pollution from Ships, 1973 (selanjutnya disebut Protocol MARPOL) sebagai instrumen hukum internasional yang menjelaskan secara rinci tentang marine pollution. Padahal secara khusus tujuan ke-14 dari Sustainable Development Goals menuntut pemimpin untuk mengurangi sampah plastik dan sumber marine pollution. Walaupun marine pollution sudah menjadi isu global, banyaknya kasus tentang kerusakan lingkungan akibat sampah plastik ataupun limbah dan sudah diberitakan di media sosial. Namun, tetap saja negara-negara dalam praktiknya belum memiliki tanggung jawab untuk melindungi ekosistem yang ada di laut. Berbagai instrumen hukum internasional masih diabaikan UNCLOS dan hanya bersifat pembukuan aturan hukum laut saja dengan tidak mempedulikan aspek-aspek perlindungan lingkungan sebagai prioritas nasional yang tinggi.

Berdasarkan uraian tersebut di atas, maka penelitian ini bertujuan untuk mengurai strategi beberapa negara dalam menyikapi marine pollution. Lebih lanjut, penelitian ini juga akan menganalisis keberlakuan instrumen hukum internasional dalam menyikapi marine pollution.

\section{METODE}

Penelitian ini menggunakan pendekatan perundang-undangan (statute approach) dan pendekatan konseptual (conceptual approach), dimana pendekatan penelitian tidak hanya mengacu pada peraturan perundang-undangan, namun juga mencakup prinsip-prinsip hukum yang disampaikan oleh pendapat-pendapat sarjana maupun doktrin-doktrin hukum untuk membangun argumentasi hukum dalam menyelesaikan isu hukum. ${ }^{9}$ Jenis dan sumber data yaitu terdiri dari bahan hukum primer dan sekunder, dimana bahan hukum primer meliputi materi hukum yang berbentuk formal baik peraturan perundang-undangan maupun peraturan pelaksanaan, sedangkan bahan hukum sekunder merupakan publikasi terkait hukum dan tidak termasuk dokumen resmi, ${ }^{10}$ meliputi buku-buku hukum, jurnal-jurnal hukum, skripsi atau penelitian terdahulu, situs-situs di internet, dan sebagainya yang berkaitan dengan isu hukum. Sumber ataupun bahan hukum yang telah dikumpulkan, selanjutnya akan diidentifikasi, klasifikasi dan sistematisasi sesuai permasalahan penelitian. Analisis data dalam penelitian ini dilakukan melalui cara menelaah sumber ataupun bahan hukum tertulis. Hasil telaah tersebut diinterpretasikan menggunakan metode interpretasi yang sistematis, gramatikal, dan, teleologis.

\footnotetext{
${ }^{9}$ Peter Mahmud Marzuki. (2016). Penelitian Hukum. Jakarta: Kencana Prenada Media Group, hlm. 7 - 8.

${ }^{10}$ Ibid.
} 


\section{HASIL DAN PEMBAHASAN}

\section{A. Praktik Negara dalam Menghadapi Marine Pollution}

\section{Australia}

Pemakaian plastik di Negara Australia, mencapai 1.433.046 ton plastik digunakan pada tahun 2010 - 2011, dimana hanya 20\% yang didaur ulang. Selain itu, sekitar $37 \%$ dari plastik ini untuk pembuatan kemasan sekali pakai. ${ }^{11}$ Plastik diangkut dari daerah berpenduduk ke lingkungan laut melalui sungai, angin, pasang surut, air hujan, saluran pembuangan, pembuangan limbah, dan bahkan sampai peristiwa banjir. Hal ini, dapat mencapai laut dari kapal dan instalasi lepas pantai. ${ }^{12}$ Begitu berada di lautan, sampah plastik akan mengapung di permukaan laut, atau tenggelam ke dasar laut jika terbuat dari polimer yang lebih padat daripada air laut. ${ }^{13}$ Plastik yang mengapung dapat dibuang ke darat oleh arus atau angin pantai, ${ }^{14}$ atau dapat memasuki lautan terbuka, di mana sampah plastik cenderung terakumulasi di zona konvergensi seperti yang terbentuk oleh lima pilin berskala besar (Pasifik Selatan dan Utara, Atlantik Selatan, Utara, dan India). ${ }^{15}$

Pengakuan Australia terhadap ancaman plastik yang menyebabkan ekosistem laut sebagian besar terbatas pada dampak dari puing-puing yang relatif besar (misalnya jaring ikan yang terbengkalai, kantong plastik) pada mega fauna laut (misalnya kura-kura, mamalia, burung). ${ }^{16}$ Langkah yang dilakukan oleh Australia terhadap pencemaran di laut ialah menuju pemahaman yang lebih baik tentang tingkat bahaya plastik laut terhadap organisme dan lingkungan Australia yang dimana penilaian yang lebih baik tentang kejadian dan karakteristik puing-puing plastik di laut.

\section{Indonesia}

Strategi yang dilakukan oleh Indonesia terhadap marine pollution ialah Rencana Aksi Nasional (RAN) Pengelolaan Sampah Plastik di Laut 2017 2025 yang dimana dalam pelaksanaannya membuat payung hukum program kantung plastik berbayar dan mendorong pemanfaatan sampah plastik sebagai campuran aspal. ${ }^{17}$ Adapun peraturan perundang-undangan yang ada

\footnotetext{
${ }^{11}$ Kyle O'Farrell. (2011). PACIA 2011 National Plastics Recycling Survey (2010-11 Financial Year). North Melbourne: Sustainable Resource Use Pty Ltd., hlm. 4.

${ }^{12}$ Peter G. Ryan, et al. (2009). Monitoring the Abundance of Plastic Debris in the Marine Environment. Philosophical Transactions of the Royal Society B: Biological Sciences, 364, hlm. 2004.

${ }^{13}$ Anthony L. Andrady. (2011). Microplastics in the Marine Environment. Marine Pollution Bulletin, Elsevier, 62(8), hlm. 1599.

${ }^{14}$ Martin Thiel, et al. (2013). Anthropogenic Marine Debris in the Coastal Environment: A Multi-Year Comparison Between Coastal Waters and Local Shores. Marine Pollution Bulletin, Elsevier, 71(1 - 2), hlm. 309.

${ }^{15}$ Marcus Eriksen, et al. (2013). Plastic Pollution in the South Pacific Subtropical Gyre. Marine Pollution Bulletin, Elsevier, 68(1 - 2), hlm. 74 .

${ }^{16}$ Editorial (Ed.) (2009). Background Paper for the Threat Abatement Plan for the Impacts of Marine Debris on Vertebrate Marine Life. Canberra: Australian Government Department of the Environment, Water, Heritage and the Arts, hlm. 3.

17 Teddy Prasetiawan. (2018). Upaya Mengatasi Sampah Plastik di Laut. Info Singkat: Pusat Pengkajian Pengolahan Data dan Informasi (P3DI), Pusat Penelitian Badan Keahlian DPR RI, 10(10), hlm. 15.
} 
di Indonesia untuk mengantisipasi marine pollution yakni, Undang-Undang Republik Indonesia Nomor 4 Tahun 1982 tentang Ketentuan-Ketentuan Pokok Pengelolaan Lingkungan Hidup dan dicabut dengan Undang-Undang Republik Indonesia Nomor 23 Tahun 1997 tentang Pengelolaan Lingkungan Hidup dan dicabut lagi dengan Undang-Undang Republik Indonesia Nomor 32 Tahun 2009 tentang Perlindungan dan Pengelolaan Lingkungan Hidup, UndangUndang Republik Indonesia Nomor 21 Tahun 1992 tentang Pelayaran dan dicabut dengan Undang-Undang Republik Indonesia Nomor 21 Tahun 2008 tentang Pelayaran, Peraturan Pemerintah Republik Indonesia Nomor 19 Tahun 1999 tentang Pengendalian Pencemaran dan/atau Perusakan Laut, Peraturan Pemerintah Republik Indonesia Nomor 51 Tahun 2002 tentang Perkapalan, dan Keputusan Menteri Perhubungan Republik Indonesia Nomor 86 Tahun 1990 tentang Pencegahan Pencemaran oleh Minyak dari Kapal-Kapal dan dicabut dengan Peraturan Menteri Perhubungan Republik Indonesia Nomor KM. 4 Tahun 2005 tentang Pencegahan Pencemaran dari Kapal ${ }^{18}$ dan dicabut lagi dengan Peraturan Menteri Perhubungan Republik Indonesia Nomor PM 29 Tahun 2014 tentang Pencegahan Pencemaran Lingkungan Maritim.

\section{Amerika}

Amerika Serikat memiliki lebih dari 100.000 mil dari garis pantai. Lebih dari 46.000 kapal komersial yang terdaftar secara federal, 65.000 kapal penangkap ikan komersial yang tidak terdaftar, 2.000 kapal milik pemerintah dan 4,5 juta perahu rekreasi mengarungi perairan ini. Potensi pencemaran air limbah dari kapal-kapal ini diperkirakan sama dengan polusi yang ditimbulkan oleh penduduk kota seukuran San Diego. ${ }^{19}$ Menurut Lloyd's of London, sekitar 71.000 kapal dagang beroperasi pada tahun $1979 .{ }^{20}$ Manusia di kapal penumpang sendiri menghasilkan 28.000 ton sampah per tahun. ${ }^{21}$ Pedagang laut kru dan penumpang kapal pesiar diperkirakan berkontribusi 110.000 ton dan 103.000 ton sampah per-tahun. ${ }^{22}$ Intinya, hampir semua sampah dan sampah dari armada komersial dunia dibuang langsung ke laut. ${ }^{23}$ National Academy of Sciences memperkirakan bahwa sampah yang dibuang ke lautan dunia, dikategorikan sebagai berikut: ${ }^{24}$

\footnotetext{
${ }^{18}$ Diah Okta Permata W., Irma Gusmayanti, \& Ria Maya Sari. (2014). Penerapan Pengaturan Pembuangan Limbah Minyak ke Laut oleh Kapal Tanker Dilihat dari Perspektif Hukum Lingkungan di Indonesia. Jurnal Hukum Lingkungan Indonesia, Indonesian Center for Environmental Law (ICEL), 1(1), hlm. 161 - 164.

${ }^{19}$ Frank P. Grad. (1971). Environmental Law: Sources and Problems. New York: Matthew Bender, hlm. 2 - 13.

${ }^{20}$ Nancy Wallace. (1985). Debris Entanglement in the Marine Environment: A Review. Dalam Proceedings of the Workshop on the Fate and Impact of Marine Debris. U.S. Department of Commerce, 54, hlm. 260.

${ }^{21}$ Lihat Sebastian A. Gerlach. (1981). Marine Pollution: Diagnosis and Therapy. Heidelberg: Springer-Verlag Berlin, hlm. 200.; Lihat juga Allen L. Springer. (1977). Towards a Meaningful Concept of Pollution in International Law. International \& Comparative Law Quarterly, Cambridge University Press, 26(3), hlm. 534.

${ }^{22}$ Sebastian A. Gerlach. (1981). Ibid., hlm. 201.

${ }^{23}$ Homer A. Neal \& J. R. Schubel. (1987). Solid Waste Management and the Environment: The Mounting Garbage and Trash Crisis. New Jersey: Prentice Hall, hlm. 67.

${ }^{24}$ Ibid., hlm. 68.
} 

a. bahan kertas $-63 \%$;
b. $\operatorname{logam}-16,6 \%$;
c. $\quad$ kaca $-9,6 \%$;
d. plastik $-0,7 \%$; dan
e. $\quad$ karet $-0,5 \%$.

Meskipun plastik hanya terdiri dari sebagian kecil limbah padat yang dibuang ke lautan, dampaknya yang berbahaya bagi lingkungan dan kelihatannya omnipresensi menjadikannya fokus yang tepat dalam mendiskusikannya. ${ }^{25}$ Diperkirakan 639.000 plastik kontainer dibuang setiap hari ke laut. Dalam rangka menanggulangi dan mencegah penyebaran sampah yang lebih luas lagi, pada dasarnya Amerika Serikat memiliki beberapa peraturan perundangundangan yakni: Pertama, Public Law Nomor 92-500 Tahun 1972 tentang Federal Water Pollution Control Act Amendments of 1972 (selanjutnya disebut CWA), dimana peraturan ini dibuat untuk memberikan perlindungan terhadap kualitas perairan darat dari limbah kimia dan limbah padat, sehingga perairan tersebut dapat digunakan kembali untuk berenang, pemancingan, dan aktivitas-aktivitas lainnya. ${ }^{26}$ Kedua, Public Law Nomor 109-449 Tahun 2006 tentang Marine Debris Research, Prevention, and Reduction Act (selanjutnya disebut MDPRA), dimana peraturan ini dibuat untuk menangani pencemaran yang sudah ada di laut dan dikhususkan untuk membersihkan marine debris, sebagaimana berdasarkan Pasal 2 ayat (1) MDPRA mengatur bahwa:

\section{"Tujuan dari Undang-Undang ini adalah untuk membantu mengidentifikasi, menentukan sumber, menilai, mengurangi dan mencegah marine debris dan dampak negatifnya terhadap lingkungan laut dan keselamatan navigasinya."}

\section{Jepang}

Dalam empat bulan pertama 2015, 15.000 wadah plastik telah tersapu di pantai Jepang. Sebagian besar sampah berasal dari Korea Selatan dan Cina karena hampir semua yang jatuh di perairan lepas pantai selatan berakhir di pantai Jepang. Dalam praktiknya Jepang sendiri memberlakukan kepada masyarakat untuk memilah sampah mana yang harus didaur ulang, tidak bisa di daur ulang dan yang bisa terbakar serta Organisasi Global seperti Ocean Conservancy, yayasan surfider dan pembersihan lautan bersama kelompok nasional seperti Kementerian Lingkungan Hidup Jepang terlibat aktif dalam operasi pembersihan di lautan. ${ }^{27}$

${ }^{25}$ Lihat Edward J. Carpenter \& K. L. Smith Jr. (1972). Plastics on the Sargasso Sea Surface. Science, American Association for the Advancement of Science, 175(4027), hlm. 1240 - 1241.; Lihat juga John B. Colton Jr., Frederick D. Knapp, \& Bruce R. Burns. (1974). Plastic Particles in Surface Waters of the Northwestern Atlantic. Science, American Association for the Advancement of Science, 185(4150), hlm. 496.

${ }^{26}$ Claudia Copeland. (2010, April 23). Clean Water Act: A Summary of the Law. Dalam CRS Report for Congress. Washington, D.C.: Congressional Research Service, hlm. 2.

${ }^{27}$ Editorial. (2015, 11 November). Loc. Cit. 


\section{B. Kasus Hukum Internasional terkait Marine Pollution}

\section{Pollution of the Muktuk Ocean through Ocean Fertilization}

Rinnuco secara tidak sah mencemari lingkungan laut Samudra Muktuk yang dimana termasuk sumber daya bersama antara Aeolia dan Rinnuco yang terletak di dekat Greenland di Lingkaran Arktik. Kedua negara berbagi tugas untuk melindungi dan melestarikan lingkungan laut dan Cetacea, seperti Narwhals. Rinnuco, tanpa persetujuan Aeolia, telah melakukan pemupukan laut di Samudra Muktuk. Pemupukan laut adalah teknik rekayasa iklim yang digunakan untuk menghilangkan karbon dioksida dari atmosfer melalui pengenalan nutrisi buatan ke permukaan laut. Penggunaan pemupukan laut saat ini ditentang karena efek negatifnya terhadap keanekaragaman hayati laut. Sembilan minggu setelah percobaan pemupukan laut yang dilakukan oleh Rinnuco, sembilan narwhal mati ditemukan di lepas pantai Rinnuco. ${ }^{28}$

Rinnuco mengingkari kewajibannya untuk mencegah, mengurangi dan mengendalikan polusi ${ }^{29}$ yang dimana Pertama, Rinnuco melanggar Pasal 210 ayat (2) UNCLOS yang mengatur bahwa:

"Negara harus mengambil langkah-langkah lain yang mungkin diperlukan untuk mencegah, mengurangi dan mengendalikan polusi tersebut."

Kedua, Rinnuco melanggar kewajibannya untuk melestarikan lingkungan laut, ${ }^{30}$ sebagaimana berdasarkan Pasal 192 UNCLOS mengatur bahwa "Negara memiliki kewajiban untuk melindungi dan melestarikan lingkungan laut". Selanjutnya, Kegiatan pemupukan laut yang dilakukan Rinnuco dapat secara langsung dimasukkan sebagai tindakan pelanggaran, ${ }^{31}$ dimana berdasarkan Pasal 194 ayat (1) UNCLOS mengatur bahwa:

"Negara-negara harus mengambil, ... semua tindakan ... yang diperlukan untuk mencegah, mengurangi, dan mengendalikan polusi lingkungan laut dari sumber manapun, ... ."

Lebih lanjut, Kegiatan Pemindahan langsung besi sulfat, polutan yang dilakukan Rinnuco juga merupakan tindakan pelanggaran, ${ }^{32}$ dimana berdasarkan Pasal 195 UNCLOS mengatur bahwa:

"Negara-negara harus bertindak agar tidak memindahkan, secara langsung atau tidak langsung, kerusakan atau bahaya dari satu daerah ke daerah lain atau mengubah satu jenis pencemaran menjadi yang lain."

\footnotetext{
${ }^{28}$ International Court of Justice. Memorial of the Applicant the Federal State of Aeolia. Dalam Case concerning Pollution of the Muktuk Ocean through Ocean Fertilization, hlm 1.

${ }^{29}$ Ibid., hlm 2.

${ }^{30}$ Ibid., hlm 3.

${ }^{31}$ Ibid.

${ }^{32}$ bid., hlm 4 .
} 
Pelepasan zat besi ke laut menyebabkan ganggang di satu wilayah mengkonsumsi semua nutrisi lain. ${ }^{33}$ Ini menghasilkan sirkulasi air yang kekurangan nutrisi penting yang diperlukan untuk menjaga lingkungan laut yang sehat. ${ }^{34}$ Sementara Rinnuco membatasi proyek dalam 200 bahari bermil-mil dari pantainya sendiri, dampak kimia dari pemupukan laut telah mengakibatkan kerusakan pada Samudra Muktuk. Setiap inisiasi ulang proyek akan mengancam kesejahteraan lingkungan laut Aeolia di masa depan.

Ketiga, Rinnuco melanggar kewajibannya untuk melestarikan kehidupan laut yang rentan sebagaimana berdasarkan Pasal 64 ayat (1) UNCLOS mengatur bahwa:

"Negara pantai dan Negara-negara lain yang warganegaranya menangkap ikan di wilayah tersebut untuk spesies yang sangat bermigrasi yang tercantum dalam Lampiran I, harus bekerja sama secara langsung atau melalui organisasi internasional yang tepat dengan tujuan untuk memastikan konservasi dan mempromosikan tujuan pemanfaatan optimal spesies tersebut di seluruh wilayah, baik di dalam dan di luar zona ekonomi eksklusif."

Dari ketentuan di atas, Lampiran 1 secara khusus mencantumkan Narwhal layak mendapatkan perlindungan khusus untuk tujuan ini, dimana sifat migrasi narwhal dengan beberapa rekor penyelaman melebihi $1500 \mathrm{~m}$, narwhals adalah salah satu mamalia laut penyelam terdalam, dan dengan rekor penyelaman maksimum $1864 \mathrm{~m}$, narwhal menyaingi beberapa paus penyelam lainnya. ${ }^{35}$

Keempat, Rinnuco gagal mematuhi arahan untuk mempertimbangkan kesejahteraan spesies migrasi, yang mengakibatkan kematian sembilan narwhal. ${ }^{36}$

\section{Lake Lanoux Arbitration}

Spanyol berpendapat bahwa proyek Perancis mempengaruhi seluruh sistem air Carol dan pengalihan air akan mengubah dan menurunkan fitur fisik dari cekungan hidrografi. Pengadilan arbitrase menolak klaim Spanyol karena gagal menunjukkan bahwa: ${ }^{37}$

"Proyek itu akan menimbulkan pencemaran air sungai Carol yang mengalir dari Lake Lanoux ke Spanyol dan dimana air yang dialihkan akan dikembalikan atau air yang dikembalikan akan memiliki komposisi kimia atau suhu atau karakteristik lain yang dapat melukai minat Spanyol."

\footnotetext{
${ }^{33}$ Michelle Allsopp, David Santillo, \& Paul Johnston. (2007). A Scientific Critique of Oceanic Iron Fertilization as a Climate Change Mitigation Strategy. Dalam Greenpeace Research Laboratories Technical Note 07. Inggris: University of Exeter, hlm. 3.

${ }^{34}$ Ibid.

${ }^{35}$ M. P. Heide-Jørgensen. (2009). Narwhal (Monodon Monoceros). Dalam Encyclopedia of Marine Mammals, diedit oleh William F. Perrin, Bernd Würsig, \& J. G. M. Thewissen, (hlm. 754 - 758). London: Academic Press, hlm. 757.

${ }^{36} \mathrm{M}$ International Court of Justice. Memorial of the Applicant the Federal State of Aeolia. Dalam Case concerning Pollution of the Muktuk Ocean through Ocean Fertilization, Loc. Cit.

${ }^{37}$ Arbitral Tribunal Tahun 1957 tentang Lake Lanoux Arbitration (France v. Spain), hlm. 35.
} 


\section{Construction of a Road in Costa Rica along the San Juan River}

Dalam memorialnya, Nikaragua mengajukan Tindakan yang telah dilakukan Kosta Rika adalah membuang sedimen dan puing-puing dalam jumlah besar ke Sungai San Juan, melakukan deforestasi besar-besaran di pepohonan sepanjang Sungai San Juan, merubah topografi di sepanjang sungai, meninggalkan tumpukan tanah sewaktu-waktu dapat terancam longsor dengan adanya hujan, gagal dalam membangun sistem drainase yang tepat dalam menangani setiap akibat yang ditimbulkan konstruksi tersebut. ${ }^{38}$ Menetapkan bahwa Nikaragua memiliki kedaulatan akan Sungai San Juan, dan dikatakan bahwa Kosta Rika sama sekali tidak memiliki hak untuk membuang limbah ke sungai tersebut. ${ }^{39}$

\section{Pulp Mills on the River Uruguay}

Uruguay dan Argentina memiliki Statutes of the River Uruguay $1975{ }^{40}$ dengan adanya kesepakatan tersebut melalui Comision Administradora del Rio Uruguay (CARU) para pihak secara bersama-sama mengelola Sungai Uruguay, yang letaknya bersebelahan antara dua negara tersebut. Argentina mendasarkan klaimnya, walaupun oleh International Court of Justice dinyatakan tidak terbukti bahwa pembangunan pabrik tersebut tidak sesuai dengan prinsip hukum internasional terkait sustainable development, dimana marine pollution dapat mengakibatkan ekosistem laut semakin rusak sehingga tidak dapat lagi dimanfaatkan secara keberlanjutan. ${ }^{41}$

\section{The Mox Plant Case}

Dalam Pertimbangan Hakimnya menyatakan bahwa Untuk mencegah, mengurangi, dan mengontrol polusi di Irish Sea Pertama, sesuai dengan Pasal 192, 194, 207, 211, 212, dan 213 UNCLOS. Kedua, untuk bekerja sama dengan Irlandia dalam hal perlindungan lingkungan kelautan atas Laut Irlandia sesuai dengan Pasal 123 dan 197. Ketiga, untuk menilai dampak yang potensial atas the Mox Plant Case dan aktivitas terkaitnya terhadap lingkungan kelautan di Irish Sea sesuai dengan Pasal 206. ${ }^{42}$

\footnotetext{
${ }^{38}$ International Court of Justice. (2012). Memorial of the Republic of Nicaragua. Dalam Dispute Concerning Construction of a Road in Costa Rica along the San Juan River (Nicaragua v. Costa Rica). Republica de Nicaragua, America Central, 1, hlm. $45-76$.

${ }^{39}$ Ibid., hlm $123-128$.

${ }^{40}$ International Court of Justice. (2010). Reports of Judgments, Advisory Opinions and Orders. Dalam Case Concerning Pulp Mills on the River Uruguay (Argentina v. Uruguay), hlm. 18.

${ }^{41}$ Loura Hardjaloka. (2015). Perspektif Hukum Internasional Atas Pencemaran Laut yang Berasal dari Darat dan Praktek Penanganannya di Beberapa Negara (International Law Perspective on Land-Based Sources Pollution and Treatment Practices in Several Countries). Jurnal Legislasi Indonesia, Kementerian Hukum dan Hak Asasi Manusia RI, 12(2), hlm. 5.

${ }^{42}$ Oslo and Paris Commissions tentang Convention for the Protection of the Marine Environment of the North-East Atlantic, 1972, hlm. 382.
} 


\section{Strategi Menghadapi Marine Pollution ditinjau dari Perbandingan Praktik Negara dalam Instrumen Hukum Internasional}

Ketika lautan menjadi tercemar, itu bukan tugas yang mudah untuk membersihkannya karena tidak ada seorang pun yang bisa membersihkan lautan yang hampir seluruhnya $70 \%$ perairan. ${ }^{43}$ Sementara, kemampuan laut untuk mengasimilasi materi yang dapat terdegradasi sangat mengesankan, begitu material asing mencapai lautan, sampah plastik ataupun limbah tetap ada di sana selamanya. Karena itu, Mencatat input yang memadai dan survei sistematis tingkat kontaminasi lingkungan diperlukan. ${ }^{44}$

Secara keseluruhan, kemudian, limbah yang hampir tidak terkontrol yang secara konstan menginvasi lingkungan laut dan memiliki efek yang masih belum diteliti secara ilmiah. Belum ada dasar ilmiah yang kuat untuk mengendalikan polusi limbah yang dihasilkan kapal. Ada kekurangan data yang dapat diandalkan tentang input keseluruhan dan bahkan lebih sedikit data mengenai efek biologisnya terhadap manusia dan lingkungan. ${ }^{45}$ Oleh karena itu, dengan melihat berbagai perbandingan praktik negara bisa mengambil kebijakan yang strategis dan bisa diimplementasikan dalam hukum internasional. Menilai terhadap praktiknya yang dilakukan di Negara Australia mengambil langkah untuk melihat tingkat bahaya plastik yang mengapung di daerah lautan. Dalam hal ini, Australia mengambil langkah tersebut untuk meningkatkan kesadaran terhadap masyarakat untuk tidak membuang sampah plastik maupun limbah yang dapat menyebabkan marine pollution. Terhadap Negara Amerika lebih mendahulukan peraturan perundangundangannya terlebih dahulu. Hal ini bisa dilihat dari CWA dan MDPRA. Begitupula degan Negara Indonesia dengan strategi membuat payung hukum program kantung plastik berbayar dan mendorong pemanfaatan sampah plastik sebagai campuran aspal. Berbeda dengan Negara Jepang yang sudah dibiasakan untuk memilah sampah dari awal sejarahnya yang sangat memperhatikan kebersihan yang dimana pemerintahnya juga menjadi teladan untuk membersihkan pencemaran di lautan yang dikirim dari daerah Korea dan China.

Mengingat dalam artikel ini terdapat lima kasus yang diambil sebagai referensi marine pollution. diantaranya, Pertama, kasus yang berkaitan dengan pencemaran di sungai ialah Lake Lanoux Arbitration, Construction of a Road in Costa Rica along the San Juan River, dan Pulp Mills on the River Uruguay. Kedua, kasus yang berkaitan langsung dengan lautan ialah Pollution of the Muktuk Ocean through Ocean Fertilization dan The Mox Plant Case. Menimbang, semua kasus tersebut dengan praktik negara menunjukkan ketidakpedulian terhadap masyarakat internasional maupun dunia internasional terhadap pentingnya perlindungan laut atas segala

\footnotetext{
${ }^{43}$ John A. Knauss. (1973, 18 - 21 Juni). Ocean Pollution: Status and Prognostication. Dalam Law of the Sea: The Emerging Regime of the Oceans. Kingston: University of Rhode Island, hlm. 321.

${ }^{44}$ Ibid., hlm. 314.

${ }^{45}$ Sonja Boehmer-Christiansen. (1982). The Scientific Basis of Marine Pollution Control. Marine Policy, Elsevier, 6(1), hlm. 5.
} 
pencemaran yang bersumber dari dumping (pembuangan secara sengaja ke laut) dan praktik negara pula yang membangun proyek sebagai wujud ketidakpedulian terhadap lingkungan laut.

Maka, instrumen Hukum Internasional dalam artikel kali ini menggunakan Pertama, International Maritime Organization Tahun 1972 tentang Convention on the Prevention of Marine Pollution by Dumping of Wastes and Other Matter (selanjutnya disebut London Convention) dan dicabut dengan International Maritime Organization tentang 1996 Protocol to the Convention on the Prevention of Marine Pollution by Dumping of Wastes and Other Matter, 1972 (selanjutnya disebut Protocol 1996) dimana merupakan instrumen hukum internasional yang bertujuan untuk mengendalikan marine pollution yang bersumber dari pembuangan limbah dan bahan lainnya yang dilakukan secara sengaja. ${ }^{46}$ Dalam London Convention maupun Protocol 1996, tidak diatur secara khusus mengenai mekanisme tanggung jawab perdata apabila terjadi dumping, namun kita dapat melihat salah satu upaya penegakan hukum lingkungan dalam ranah perdata jika terjadi kerugian atau pencemaran yang dianut oleh Protocol 1996 adalah penerapan prinsip pencemar membayar (polluter pays principle). Sebagai pelaksana London Convention, menunjuk IMO (International Maritime Organization) sebagai sekretariat yang akan melaksanakan tugas dari London Convention ini. Dalam hal ini, konsensus International Maritime Organization (IMO) melalui Protocol MARPOL. Kedua, Pasal 194 ayat (1) jo. ayat (2) UNCLOS dimana mewajibkan Negara-negara untuk melakukan semua tindakan yang diperlukan untuk mencegah, mengurangi dan mengontrol pencemaran laut dari sumber apapun sesuai dengan kemampuan masing-masing Negara serta mengambil semua langkah yang diperlukan untuk memastikan bahwa kegiatan yang dilakukan dalam kewenangan atau kontrolnya agar tidak menimbulkan pencemaran yang dapat menyebabkan kerusakan (duty not to transfer) pada wilayahnya sendiri atau wilayah negara lain. ${ }^{47}$

Lebih lanjut, UNCLOS memberikan pendekatan paling komprehensif untuk masalah marine pollution, sekalipun juga masih terdapat kekurangan. UNCLOS memberikan prinsip umum yang luas namun tidak memiliki perincian secara spesifik yang diperlukan untuk administrasi efektif dari rezim pengendalian pencemaran internasional. Pasal 192 UNCLOS mengatur bahwa "Negara memiliki kewajiban untuk melindungi dan melestarikan lingkungan laut". UNCLOS lebih mementingkan pendefinisian hak dan kewajiban yurisdiksi negara-negara bendera, pantai, dan pelabuhan daripada dalam standar substantif yang rumit. Biasanya, konvensi tersebut mempertimbangkan polusi minyak yang dimana ketika merancang ketentuannya tentang polusi yang ditimbulkan oleh kapal, bencana Torrey Canyon telah terjadi sesaat sebelum dimulainya konferensi. Sayangnya, bagaimanapun, tidak ada ketentuan yang secara khusus menangani pembuangan sampah dan limbah.

\footnotetext{
${ }^{46}$ Diah Okta Permata W., Irma Gusmayanti, \& Ria Maya Sari. (2014). Op. Cit., hlm. 157.

${ }^{47}$ Jonathan I. Charney. (1994). The Marine Environment and the 1982 United Nations Convention on the Law of the Sea. The International Lawyer, American Bar Association, 28(4), hlm. 886 - 887.
} 
Belum adanya aturan yang ketat mengenai ganti rugi terhadap marine pollution atau peraturan yang benar-benar menyeluruh mengenai marine pollution itu sendiri. Tidak ada bukti bahwa jenis polusi ini menjadi perhatian di konferensi internasional. UNCLOS seharusnya melihat ke Protocol MARPOL, khususnya Lampiran IV dan V, untuk panduan. Rupanya pemikiran konferensi adalah bahwa karena banyak konferensi bilateral dan regional yang membahas berbagai aspek dan sumber marine pollution, UNCLOS tidak perlu menyediakan pendekatan yang terperinci dan teknis untuk masalah pencemaran. Namun, jika penggunaan instrumen hukum internasional diperlukan ialah dengan menggunakan instrumen yang di luar ruang lingkup konvensi Karena konvensi tersebut adalah produk dari "paket kesepakatan", rezim polusi standar yang terperinci akan datang dengan mengorbankan konsensus. Negara-negara berkembang tidak menganggap perlindungan lingkungan sebagai prioritas nasional yang tinggi seperti yang dilakukan oleh negara-negara maju. Sebagaimana Negara Jepang dalam sejarahnya hingga kini menerapkan kebiasaan terhadap masyarakat untuk menjaga lingkungan apalagi termasuk lingkungan laut yang dimana dalam menghasilkan pendapatan ialah dengan ikan terbesar yang diproksi oleh Jepang sendiri. Namun, berbeda dengan pandangan negara berkembang yang melihat instrumen hukum internasional ini sebagai promosi kekuatan utama konservasi. Pendekatan ini dipandang sebagai upaya untuk membatasi perkembangan Dunia Ketiga.

Marine pollution negara lain merupakan pelanggaran hukum internasional, sebagaimana dibuktikan dari praktik negara dan pendapat-pendapat hukum selama bertahun-tahun, dan karenanya mengikat hampir semua negara bagian. Dengan asumsi, arguendo, bahwa perlindungan lingkungan telah mencapai tingkat hukum kebiasaan internasional, ketentuan yang sangat umum dan luas dari Bagian XII dari UNCLOS akan dianggap hanya sebagai kodifikasi hukum internasional. Dapat diperdebatkan, sebagai hasil dari praktik negara yang luas selama periode waktu yang substansial, dan sebagaimana dibuktikan oleh perjanjian bilateral, regional dan multilateral, pencegahan marine pollution mungkin telah meningkat ke tingkat hukum internasional.

Protocol MARPOL terdiri dari 6 (enam) Lampiran-lampiran, yang masing-masing diberlakukan untuk jenis pencemaran laut dan udara dari kapal yang berbeda, sebagai berikut:

1. Lampiran I: Minyak (Oil), diberlakukan untuk kapal-kapal barang niaga yang dikategorikan sebagai kapal tangki minyak yang mengangkut minyak dalam bentuk curah;

2. Lampiran II: Bahan-bahan Beracun Cair yang diangkut dalam bentuk Curah (Noxious Liquid Substances carried in Bulk), diberlakukan untuk kapal-kapal barang niaga yang dikategorikan sebagai kapal tangki kimia yang mengangkut bahan-bahan cair kimia atau beracun dan minyak nabati dalam bentuk curah; 
3. Lampiran III: Bahan-bahan Berbahaya yang diangkut dalam bentuk kemasan (Harmful Substances carried in Packaged Form), diberlakukan untuk kapalkapal barang dan penumpang niaga yang mengangkut muatan bahan-bahan berbahaya dalam bentuk kemasan;

4. Lampiran IV: Limbah Air Kotor (Sewage), diberlakukan untuk kapal-kapal barang dan penumpang niaga yang berawak dan membawa orang atau penumpang yang dapat menimbulkan limbah air kotor;

5. Lampiran V: Limbah Sampah (Garbage), diberlakukan untuk kapal-kapal barang dan penumpang niaga yang dapat menimbulkan limbah sampah;

6. Lampiran VI: Pencemaran Udara (Air Pollution), diberlakukan untuk kapal-kapal barang dan penumpang niaga yang membawa muatan dan/atau menggunakan tenaga mesin pendorong dan mesin bantu lain yang dapat menghasilkan gas buang pencemar.

Dari lampiran Protocol MARPOL, artikel ini menunjukkan ganti rugi terhadap marine pollution dimana tidak diatur secara menyeluruh dalam konvensi ini. Sehingga, pada akhirnya ganti rugi harus dibebankan kepada Konvensi CLC. Terkait instrumen hukum internasional mengenai marine pollution ini, maka strategi yang bisa dilakukan oleh seluruh dunia internasional dengan melihat berbagai perbandingan praktik negara yang dimana baik kasusnya, peraturan perundang-undangan, dan instrumen hukum internasional. Pertama, agar dapat diharmoninasikan negara satu dengan yang lainnya untuk tidak ada pandangan curiga terhadap peraturan yang dibuat sebagaimana Protocol MARPOL. Kedua, saling menyadarkan negara satu dengan yang lainnya betapa pentingnya pelindungan laut demi memenuhi kebutuhan bersama sebagaimana yang dilakukan di Negara Australia dengan meneliti dampak air lautan yang diliputi sampah plastik maupun limbah membahayakan bagi ekosistem maupun kehidupan manusia ketika menggunakan lautan itu sebagai satu-satunya penghasilan manusia. Ketiga, walaupun UNCLOS bersifat generalis tetap bisa melihat instrumen hukum internasional lain yang bisa mewujudkan aturan yang spesialis.

\section{KESIMPULAN DAN SARAN}

Dari hasil dan pembahasan di atas, uraian terkaitstrategi dalam menyikapi marine pollution, terdiri dari empat negara, antara lain Australia memilih untuk meningkatkan pemahaman masyarakat untuk tidak membuang sampah plastik maupun limbah yang dapat mengancam organisme serta mencemari lingkungan di laut. Indonesia memilih untuk membuat payung hukum program kantung plastik berbayar dan mendorong pemanfaatan sampah plastik sebagai campuran aspal. Amerika memilih untuk memprioritaskan peraturan perundangundangan, antara lain Public Law Nomor 92-500 Tahun 1972 tentang Federal Water Pollution Control Act Amendments of 1972 dan Public Law Nomor 109-449 Tahun 2006 tentang Marine Debris Research, Prevention, and Reduction Act. Jepang melalui Kementerian Lingkungan Hidup memilih untuk melibatkan segenap organisasi masyarakat dalam 
operasi pembersihan di lautan, serta memberlakukan kepada masyarakat untuk memilah sampah mana yang harus didaur ulang, tidak bisa di daur ulang, dan yang bisa dibakar. Lebih lanjut, instrumen hukum internasional dalam menyikapi marine pollution, antara lain Protocol 1996 dan UNCLOS, serta Protocol MARPOL. Protocol 1996 dan UNCLOS saling berkaitan dan tidak bisa dipisahkan, namun sebagian belum meratifikasi Protocol MARPOL sebagai bagian dari pelaksana Protocol 1996. Adapun saran-saran dalam menyikapi marine pollution secara umum, antara lain pertama, memberikan edukasi kepada masyarakat internasional agar membentuk kepeduliannya terhadap lingkungan laut. Kedua, meratifikasi instrumen hukum internasional terkait marine pollution sehingga terjadi sinkronisasi dan harmonisasi hukum yang dapat dipertanggungjawabkan oleh seluruh masyarakat internasional. Dengan demikian, strategi mengatasi marine pollution dapat diatasi melalui keterhubungan antara perbandingan praktik negara dan instrumen hukum internasional.

\section{REFERENSI}

Ahmad Sofyan. (2010). Tanggung Jawab dalam Pencemaran Laut yang Disebabkan oleh Minyak Menurut Hukum Internasional. Inspirasi, Universitas Tadulako, 10, hlm. $139-164$.

Ahmad Surya Widyansyah. (2020, 4 Maret). Kurangi Sampah Plastik Lautan, Apa Strategi Indonesia? Dalam suara.com. Diakses dari https://www.suara.com/ yoursay/2020/03/04/125908/kurangi-sampah-plastik-lautan-apa-strategiindonesia, pada tanggal 27 Mei 2020.

Allen L. Springer. (1977). Towards a Meaningful Concept of Pollution in International Law. International \& Comparative Law Quarterly, Cambridge University Press, 26(3), hlm. 531 - 557. doi: https://doi.org/10.1093/iclqaj/26.3.531

Anthony L. Andrady. (2011). Microplastics in the Marine Environment. Marine Pollution Bulletin, Elsevier, 62(8), hlm. 1596 - 1605. doi: https://doi.org/10.1016/j. marpolbul.2011.05.030

Arbitral Tribunal Tahun 1957 tentang Lake Lanoux Arbitration (France v. Spain).

Claudia Copeland. (2010). Clean Water Act: A Summary of the Law. Dalam CRS Report for Congress. Congressional Research Service, hlm. 1 - 11.

Diah Okta Permata W., Irma Gusmayanti, \& Ria Maya Sari. (2014). Penerapan Pengaturan Pembuangan Limbah Minyak ke Laut oleh Kapal Tanker Dilihat dari Perspektif Hukum Lingkungan di Indonesia. Jurnal Hukum Lingkungan Indonesia, Indonesian Center for Environmental Law (ICEL), 1(1), hlm. 155 - 180. doi: http:// dx.doi.org/10.38011/jhli.v1i1.8

Editorial (Ed.) (2009). Background Paper for the Threat Abatement Plan for the Impacts of Marine Debris on Vertebrate Marine Life. Canberra: Australian Government Department of the Environment, Water, Heritage and the Arts.

Editorial. (2015, 11 November). The Pollution Crisis in Sea of Japan. Dalam Renewable Energy World. Diakses dari https://www.renewableenergyworld.com/2015/11/11/ the-pollution-crisis-in-sea-of-japan/, pada tanggal 27 Mei 2020. 
Edward J. Carpenter \& K. L. Smith Jr. (1972). Plastics on the Sargasso Sea Surface. Science, American Association for the Advancement of Science, 175(4027), hlm. 1240 - 1241. doi: https://doi.org/10.1126/science.175.4027.1240

Frank P. Grad. (1971). Environmental Law: Sources and Problems. New York: Matthew Bender.

Homer A. Neal \& J. R. Schubel. (1987). Solid Waste Management and the Environment: The Mounting Garbage and Trash Crisis. New Jersey: Prentice Hall.

International Court of Justice. (2010). Reports of Judgments, Advisory Opinions and Orders. Dalam Case Concerning Pulp Mills on the River Uruguay (Argentina v. Uruguay).

International Court of Justice. (2012). Memorial of the Republic of Nicaragua. Dalam Dispute Concerning Construction of a Road in Costa Rica along the San Juan River (Nicaragua v. Costa Rica). Republica de Nicaragua, America Central, 1.

International Court of Justice. Memorial of the Applicant the Federal State of Aeolia. Dalam Case concerning Pollution of the Muktuk Ocean through Ocean Fertilization.

International Maritime Organization Tahun 1972 tentang Convention on the Prevention of Marine Pollution by Dumping of Wastes and Other Matter. (Disahkan pada tanggal 12 Desember 1972, di London, Mexico City, Moscow dan Washington).

International Maritime Organization Tahun 1973 tentang International Convention for the Prevention of Pollution from Ships. (Disahkan pada tanggal 2 November 1973, di London).

International Maritime Organization tentang 1996 Protocol to the Convention on the Prevention of Marine Pollution by Dumping of Wastes and Other Matter, 1972. (Disahkan pada tanggal 7 November 1996, di London).

International Maritime Organization tentang Protocol of 1978 Relating to the International Convention for the Prevention of Pollution from Ships, 1973. (Disahkan pada tanggal 17 Februari 1978, di London).

John A. Knauss. (1973). Ocean Pollution: Status and Prognostication. Dalam Law of the Sea: The Emerging Regime of the Oceans. University of Rhode Island, hlm. 313 328.

John B. Colton Jr., Frederick D. Knapp, \& Bruce R. Burns. (1974). Plastic Particles in Surface Waters of the Northwestern Atlantic. Science, American Association for the Advancement of Science, 185(4150), hlm. 491 - 497. doi: https://doi. org/10.1126/science.185.4150.491

Jonathan I. Charney. (1994). The Marine Environment and the 1982 United Nations Convention on the Law of the Sea. The International Lawyer, American Bar Association, 28(4), hlm. 879 - 901.

Keputusan Menteri Perhubungan Republik Indonesia Nomor 86 Tahun 1990 tentang Pencegahan Pencemaran oleh Minyak dari Kapal-Kapal.

Kyle O'Farrell. (2011). PACIA 2011 National Plastics Recycling Survey (2010-11 Financial Year). North Melbourne: Sustainable Resource Use Pty Ltd. 
Loura Hardjaloka. (2015). Perspektif Hukum Internasional Atas Pencemaran Laut yang Berasal dari Darat dan Praktek Penanganannya di Beberapa Negara (International Law Perspective on Land-Based Sources Pollution and Treatment Practices in Several Countries). Jurnal Legislasi Indonesia, Kementerian Hukum dan Hak Asasi Manusia RI, 12(2), hlm. 1 - 30.

M. P. Heide-Jørgensen. (2009). Narwhal (Monodon Monoceros). Dalam Encyclopedia of Marine Mammals, diedit oleh William F. Perrin, Bernd Würsig, \& J. G. M. Thewissen, (hlm. 754 - 758). London: Academic Press.

Marcus Eriksen, et al. (2013). Plastic Pollution in the South Pacific Subtropical Gyre. Marine Pollution Bulletin, Elsevier, 68(1 - 2), hlm. 71 - 76. doi: https://doi. org/10.1016/j.marpolbul.2012.12.021

Martin Thiel, et al. (2013). Anthropogenic Marine Debris in the Coastal Environment: A Multi-Year Comparison Between Coastal Waters and Local Shores. Marine Pollution Bulletin, Elsevier, 71(1 - 2), hlm. 307 - 316. doi: https://doi. org/10.1016/j.marpolbul.2013.01.005

Michelle Allsopp, David Santillo, \& Paul Johnston. (2007). A Scientific Critique of Oceanic Iron Fertilization as a Climate Change Mitigation Strategy. Dalam Greenpeace Research Laboratories Technical Note 07. Inggris: University of Exeter.

Nancy Wallace. (1985). Debris Entanglement in the Marine Environment: A Review. Dalam Proceedings of the Workshop on the Fate and Impact of Marine Debris. U.S. Department of Commerce, 54, hlm. 259 - 277.

Oslo and Paris Commissions tentang Convention for the Protection of the Marine Environment of the North-East Atlantic, 1972 (Disahkan pada tanggal 15 Februari 1972, di Oslo. Teks diamandemen pada tanggal 24 July 1998).

Peraturan Menteri Perhubungan Republik Indonesia Nomor KM. 4 Tahun 2005 tentang Pencegahan Pencemaran dari Kapal.

Peraturan Menteri Perhubungan Republik Indonesia Nomor PM 29 Tahun 2014 tentang Pencegahan Pencemaran Lingkungan Maritim. (Berita Negara Republik Indonesia Tahun 2014 Nomor 1115).

Peraturan Pemerintah Republik Indonesia Nomor 19 Tahun 1999 tentang Pengendalian Pencemaran dan/atau Perusakan Laut. (Lembaran Negara Republik Indonesia Tahun 1999 Nomor 32. Tambahan Lembaran Negara Republik Indonesia Nomor 3816).

Peraturan Pemerintah Republik Indonesia Nomor 51 Tahun 2002 tentang Perkapalan. (Lembaran Negara Republik Indonesia Tahun 2002 Nomor 95. Tambahan Lembaran Negara Republik Indonesia Nomor 4227).

Peter G. Ryan, et al. (2009). Monitoring the Abundance of Plastic Debris in the Marine Environment. Philosophical Transactions of the Royal Society B: Biological Sciences, 364, hlm. 1999 - 2012. doi: https://doi.org/10.1098/rstb.2008.0207

Peter Mahmud Marzuki. (2016). Penelitian Hukum. Jakarta: Kencana Prenada Media Group.

Public Law Nomor 92-500 Tahun 1972 tentang Federal Water Pollution Control Act Amendments of 1972. (Legislative History - S. 2770). 
Public Law Nomor 109-449 Tahun 2006 tentang Marine Debris Research, Prevention, and Reduction Act. (Legislative History - S. 362).

Safri Burhanuddin. (2017,11 September). Improving Solid Waste Management Capacity as a Tool for Combating Marine Plastic Debris Issue. Artikel dipresentasikan pada National Conference on Waste To Energy, Jakarta: Coordinating Ministry for Maritime Affairs Republic of Indonesia.

Sebastian A. Gerlach. (1981). Marine Pollution: Diagnosis and Therapy. Heidelberg: Springer-Verlag Berlin.

Sherly Puspita. (2018, 19 Agustus). Indonesia Penyumbang Sampah Plastik Terbesar Kedua di Dunia. Dalam Megapolitan, Kompas.com. Diakses dari https://megapolitan. kompas.com/read/2018/08/19/21151811/indonesia-penyumbang-sampahplastik-terbesar-kedua-di-dunia, pada tanggal 27 Mei 2020.

Sonja Boehmer-Christiansen. (1982). The Scientific Basis of Marine Pollution Control. Marine Policy, Elsevier, 6(1), hlm. 2 - 10. doi: https://doi.org/10.1016/0308597X(82)90038-0

Statutes of the River Uruguay. (Disahkan pada tanggal 26 Februari 1975, di Salto, Uruguay).

Teddy Prasetiawan. (2018). Upaya Mengatasi Sampah Plastik di Laut. Info Singkat: Pusat Pengkajian Pengolahan Data dan Informasi (P3DI), Pusat Penelitian Badan Keahlian DPR RI, 10(10), hlm. 13 - 18.

Undang-Undang Republik Indonesia Nomor 4 Tahun 1982 tentang KetentuanKetentuan Pokok Pengelolaan Lingkungan Hidup. (Lembaran Negara Republik Indonesia Tahun 1982 Nomor 12. Tambahan Lembaran Negara Republik Indonesia Nomor 3215).

Undang-Undang Republik Indonesia Nomor 21 Tahun 1992 tentang Pelayaran. (Lembaran Negara Republik Indonesia Tahun 1992 Nomor 98. Tambahan Lembaran Negara Republik Indonesia Nomor 3493).

Undang-Undang Republik Indonesia Nomor 23 Tahun 1997 tentang Pengelolaan Lingkungan Hidup. (Lembaran Negara Republik Indonesia Tahun 1997 Nomor 68. Tambahan Lembaran Negara Republik Indonesia Nomor 3699).

Undang-Undang Republik Indonesia Nomor 21 Tahun 2008 tentang Pelayaran. (Lembaran Negara Republik Indonesia Tahun 2008 Nomor 64. Tambahan Lembaran Negara Republik Indonesia Nomor 4849).

Undang-Undang Republik Indonesia Nomor 32 Tahun 2009 tentang Perlindungan dan Pengelolaan Lingkungan Hidup. (Lembaran Negara Republik Indonesia Tahun 2009 Nomor 140. Tambahan Lembaran Negara Republik Indonesia Nomor 5059).

United Nations Convention on the Law of the Sea. (Disahkan pada tanggal 10 Desember 1982, di Montego Bay, Jamaica).

\footnotetext{
I Neneng Yuni. (2020). Marine Pollution Ditinjau dari Perbandingan Praktik Negara terhadap Instrumen Hukum Internasional. SIGn Jurnal Hukum, CV. Social Politic Genius ।

I (SIGn), 2(1), hlm. 55-71. doi: https://doi.org/10.37276/sjh.v2i1.63 _ _ _ _ _ _
} 